J. Japan. Assoc. Min.

Petr. Econ. Geol.

70, $118-124,1975$

\title{
MAGNESIUM-IRON DISTRIBUTION IN COEXISTING BIOTITE AND HORNBLENDE FROM GRANITIC ROCKS
}

\author{
Hisao TANAKa \\ Department of Geology, University of Yamagata, Yamagata
}

\begin{abstract}
Coexisting biotites and hornblendes from the rocks of the Tabito plutonic complex were analysed chemically. The $\mathrm{Mg}-\mathrm{Fe}^{+2}$ distribution coefficients in the two mafic minerals, ranging from 0.74 to 0.93 , are directly proportional to the $\mathrm{Al}^{\mathrm{rV}}$ contents in the hornbendes. The relation is universal in the calc-alkaline granitic rocks of various districts.
\end{abstract}

\section{INTRODUCTION}

Concerning granite petrology, the distribution of elements in coexisting biotite and hornblende has been a current problem, as the two silicates are usually the main mafic constituents in granitic rocks. On the basis of the $\mathrm{Mg}-\mathrm{Fe}^{+2}$ distribution between coexisting biotite and hornblende, Hietanen (1971) presented some petrogenetic discussions for the granitic plutons of the Northern Sierra Nevada. It was pointed out by Ray and Sen (1970) that tetrahedral $\mathrm{Al}$ in hornblende exerted a major control on the variation of the $\mathrm{Mg}-\mathrm{Fe}^{+2}$ distribution coefficient between pyroxene and hornblende. Kanisawa (1972) showed that the $\mathrm{Mg}-\mathrm{Fe}^{+2}$ distribution coefficient between biotite and hornblende depended largely upon $\mathrm{Al}$ contents in the two minerals. According to Gorbatscev (1972), the total $\mathrm{Fe}-\mathrm{Mg}$ distribution coefficient between coexisting biotite and Ca-amphibole from metamorphic rocks and igneous rocks, mainly from the former, was controled by the octahedral substitutions as well as the tetrahedral ones.
Thus, there is a doubt whether the distribution coefficient between biotite and hornblende is sufficiently useful as an indicator of temperature or pressure, because the compositional dependance of the distribution coefficient may not be ignored.

During a petrological study of the Tabito plutonic complex in the Abukuma plateau, northeast Japan, twelve biotitehornblende pairs were analysed chemically. Based on them and other data from the calcalkaline granitic rocks of various districts,

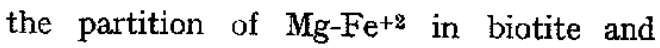
hornblende is discussed in this paper.

\section{Geological OUtline of the Tabito COMPLEX}

The Tabito plutonic complex, according: to Shido (1958), occupying an area of about $250 \mathrm{Km}^{2}$, consists of a granitic body and small gabbroic masses. The age of the Tabito complex obtained from $\mathrm{Rb}-\mathrm{Sr}$ mineral dating is $92 \mathrm{~m} . \mathrm{y}$. (Ueno, 1968), $95 \mathrm{~m} . \mathrm{y}$. by K-Ar mineral dating (Fukasawa and Onuki, 1972), and $150 \mathrm{~m} . \mathrm{y}$. by Rb-Sr whole rock dating (Maruyama, 1972). A 
detailed study of the northern part of the complex was made recently by the present author (Tanaka, 1974), and it is briefly summarized below.

The granitic body of the northern part of the Tabito plutonic complex is composed mainly of granodiorite and quartz diorite. The body is divided into three intrusive units, namely, the Myojin-ishi, Komuro and Iritabyuto types, and they are considered to have intruded successively in this order. Gabboric masses consisting mainly of hornblende gabbro with a small amount of cortlandtite and gabbro pegmatite are intruded by granitic veins of the Iritabyuto type.

The Myojin-ishi type is characterized by prismatic homblende and often contains a small amount of cummingtonite and pyroxenes. The Komuro type having no cummingtonite or pyroxene is intruded by networks of leucocratic veins at many places derived from the Iritabyuto type. The Iritabyuto type, the most leucocratic amoung the three, contains dark inclusions mainly of plaigoclase, biotite and hornblende with a small amount of quartz, and correspond to quartz diorite or diorite in mineralogical composition.

\section{Modes of OGGurRence of Biotite AND HORNBLENDE}

Biotite and hornblende are the major mafic constituents in the Myojin-ishi type, the Komuro type and the dark inclusions. In the Iritabyuto type, though the amount of biotite is fairly large, the associated homblende is usually only a little and sometimes not detected.

Biotites are generally subhedral or anhedral, and occur as independent grains or contiguous ones with hornblendes. Minute biotite replacing hornblendes however are seen sometimes. Accordingly the biotites may have crystallized almost simultaneously with hornblendes, or slightly later than the latter. Most of them are brown in $Z$-axial color, and the rest are reddish brown.

In the Myojin-ishi type, the hornblendes being usually subhedral prismatic crystals rarely contain in the core clinopyroxene or cummingtonite, and very rarely orthopyroxene. In the other two types and the dark inclusions the hornblendes are subhedral acicular crystals or ragged ones. Hornblendes from the Myojin-ishi and Komuro types ard brown, brownish green or green in $\mathrm{Z}$-axial color, and sometimes show the zoning in this order from core to margin. On the other hand, those from the Iritabyuto type and the dark inclusions are generally bluish green, and the bluish tinge is probably due to their high $\mathrm{Fe}^{+3} /\left(\mathrm{Fe}^{+2}\right.$ $+\mathrm{Fe}^{+3}$ ) ratio.

\section{Chemical Compositions of Biotite AND HoRNBLENDE}

Eleven pairs of biotite and hornblende were seperated by means of the Franz Isodynamic Separator, heavy liquid, and tapping on paper, and they were analysed chemically. In addition, one biotitehornblende pair from a gabbro in which the mode of occurrence of each mineral is similar to that in the Myojin-ishi type was also analysed. Chemical compositions of the analysed minerals and their structural formulae calculated on the basis of $24(0$, $\mathrm{OH})$ are shown in Tables 1 and 2. Chemical compositions of all host rocks except No. 7372402B were reported by Tanaka (1974).

The $\mathrm{SiO}_{2}$ content of the analysed biotites covers a narrow range (i.e. 34.435.8 wt.\%), and is slightly poorer than those from most calc-alkaline granitic rocks. 
Table 1. Chemical compositions of biotites.

\begin{tabular}{|c|c|c|c|c|c|c|c|c|c|c|c|c|}
\hline \multirow{2}{*}{$\begin{array}{l}\text { Rock Type } \\
\text { Anal. No. }\end{array}$} & \multicolumn{3}{|c|}{ Myajin-1shi } & \multicolumn{3}{|c|}{ Komuro } & \multicolumn{2}{|c|}{ Iritabyuto } & \multicolumn{3}{|c|}{ Dark inclusions } & \multirow{2}{*}{$\frac{\text { Gabbro }}{1.3}$} \\
\hline & 3 & 1 & 4 & 19 & 20 & 21 & 23 & 26 & 37 & 42 & 41 & \\
\hline D.I. & 42.93 & 44.45 & 49.65 & 45.78 & 50.33 & 51.31 & 59.06 & 64.18 & 35.84 & 48.09 & 62.11 & 29.06 \\
\hline $\mathrm{SiO}_{2}$ & 35.78 & 35.20 & 35.50 & 35.68 & 35.40 & 34.91 & 34.38 & 35.27 & 35.17 & 35.48 & 35.05 & 35.27 \\
\hline $\mathrm{TiO}_{2}$ & 3.43 & 3.85 & 3.80 & 3.86 & 3.99 & 3.92 & 3.61 & 3.81: & 2.71 & 3.51 & 3.72 & 3.52 \\
\hline $\mathrm{Al}_{2} \mathrm{O}_{3}$ & 15.84 & 15.73 & 14.67 & 15.44 & 15.22 & 16.13 & 16,47 & 14.99 & 16.11. & 15.92 & 15.65 & 15.76 \\
\hline $\mathrm{Fe}_{2} \mathrm{O}_{3}$ & 1.73 & 1.05 & 2.39 & 1.62 & 1.95 & 1.11 & 3.64 & 2.30 & 1.65 & 2.27 & 2.59 & 1.62 \\
\hline $\mathrm{FeO}$ & 17.94 & 19.33 & 18.83 & 18.03 & 19.31 & 20.61 & 18.53 & 20.37 & 19.66 & 19.41 & 20.46 & 19.35 \\
\hline Mno & 0.30 & 0.25 & 0.32 & 0.17 & 0.21 & 0.27 & 0.37 & 0.38 & 0.18 & 0.28 & 0.40 & 0.13 \\
\hline $\mathrm{MgO}$ & 11.96 & 10.95 & 10.74 & 12.00 & 10.49 & 10.22 & 9.50 & 8.71 & 11.10 & 10.09 & 8.54 & 11.24 \\
\hline $\mathrm{CaO}$ & 0.56 & 0.44 & 0.40 & 0.54 & 0.40 & 0.74 & 1.14 & 0.95 & 0.50 & 0.34 & 0.57 & 0.44 \\
\hline $\mathrm{Na}_{2} \mathrm{O}$ & 0.76 & 0.77 & 0.51 & 0.72 & 0.72 & 0.70 & 0.55 & 0.80 & 0.79 & 0.55 & 0.63 & 0.85 \\
\hline $\mathrm{K}_{2} \mathrm{O}$ & 8.53 & 8.60 & 9.03 & 8.60 & 8.90 & 7.86 & 7.64 & 8.68 & 8.20 & 8.83 & 9.01 & 8.20 \\
\hline $\mathrm{H}_{2}{ }^{\mathrm{O}+}$ & 3.41 & 3.72 & 3.38 & 3.97 & 3.63 & 4.11 & 4.47 & 3.42 & 4.06 & 3.49 & 3.40 & 3.87 \\
\hline $\mathrm{H}_{2} \mathrm{O}^{-}$ & 0.18 & 0.13 & 0.06 & 0.12 & 0.02 & 0.19 & 0.20 & 0.02 & 0.26 & D.10 & 0.02 & 0.11 \\
\hline Total & 100.42 & 100.02 & 99.63 & 100.75 & 100.24 & 100.77 & 100.50 & 99.70 & 100.39 & 100.27 & 100.04 & 100.36 \\
\hline S1 & 5.439 & 5.382 & 5.486 & 5.373 & 5.420 & 5.292 & 5.194 & 5.483 & 5.344 & 5.438 & 5.437 & 5.358 \\
\hline$A I^{I V}$ & 2.561 & 2.618 & 2.514 & 2.627 & 2.580 & 2.708 & 2.806 & 2.517 & 2.656 & 2.562 & 2.563 & 2.642 \\
\hline $\mathrm{Al}^{\mathrm{VI}}$ & 0.272 & 0.212 & 0.153 & 0.108 & 0.162 & 0.168 & 0.121 & 0.224 & 0.224 & 0.209 & 0.293 & 0.175 \\
\hline $\mathrm{Ti}$ & 0.391 & 0.442 & 0.440 & 0.436 & 0.458 & 0.446 & 0.409 & 0.444 & 0.309 & 0.404 & 0.433 & 0.401 \\
\hline $\mathrm{Fe}^{+3}$ & 0.197 & 0.120 & 0.277 & 0.183 & 0.224 & 0.126 & 0.412 & 0.268 & 0.188 & 0.261 & 0.301 & 0.185 \\
\hline $\mathrm{Fe}^{+} 2$ & 2.272 & 2.463 & 2.425 & 2.262 & 2.464 & 2.603 & 2.333 & 2.639 & 2.490 & 2.479 & 2.645 & 2.450 \\
\hline Mr. & 0.039 & 0.032 & 0.042 & 0.022 & 0.027 & 0.035 & 0.047 & 0.050 & 0.023 & 0.036 & 0.052 & 0.017 \\
\hline $\mathrm{Mg}$ & 2.727 & 2.511 & 2.490 & 2.310 & 2.409 & 2.324 & 2.153 & 2.031 & 2.530 & 2.320 & 1.987 & 2.561 \\
\hline $\mathrm{Ca}$ & 0.091 & 0.072 & 0.066 & 0.087 & 0.066 & 0.120 & 0.185 & 0.158 & 0.081 & 0.056 & 0.095 & 0.072 \\
\hline $\mathrm{Na}$ & 0.224 & 0.228 & 0.152 & 0.210 & 0.213 & 0.205 & 0.161 & 0.241 & 0.232 & 0.163 & D.189 & 0.250 \\
\hline $\mathrm{K}$ & 1.655 & 1.679 & 1.781 & 3.653 & 1.740 & 1.521 & 1.473 & 1.723 & 1.591 & 1.728 & 1.784 & 1.590 \\
\hline 애 & 3.455 & 3.792 & 3.482 & 3.985 & 3.705 & 4.153 & 4.502 & 3.544 & 4.113 & 3.566 & 3.616 & 3.920 \\
\hline $\mathrm{Mg} / \mathrm{Fe}^{+2}$ & 1.20 & 1.02 & 1.03 & 1.20 & 0.98 & 0.89 & 0.92 & 0.77 & 1.02 & 0.94 & 0.75 & 1.05 \\
\hline
\end{tabular}

Analyst: H. Tanaka.

3: Hornblende biotite quartz diorite (No. 7272011).

1: Hornblende biotite quartz diorite (No. 7281409).

4: Clinopyroxene bearing biotite hornblende quartz diorite (No. 7272613).

19: Biotite hornblende quartz diorite (No. 7272216).

20: Hornblende biotite quartz diorite (No. 7272315)

21: Hornblende biotite quartz diorite (No, 51505).

23: Hornblende biotite granodiorite (No. 7272307).

26: Hornblende biotite granodiorite (No. 51506).

37: Dark inclusion (No. 7281511A).

42: Dark inclusion (No. 7372402B)

41: Dark inclusion (No. 7331402B)

13: Biotite cummingtonite hornblende quartz gabbro (No. 80204).

So these biotites are rich in $\mathrm{Al}^{\mathrm{IV}}$ and show a composition near to the siderophylliteeastonite series.

In the hornblendes from the Myojinishi and Komuro types $\mathrm{SiO}_{2}$ tends to decrease with increasing D.I. of the host rocks, and $\mathrm{Al}_{2} \mathrm{O}_{3}, \mathrm{TiO}_{2},\left(\mathrm{Na}_{2} \mathrm{O}+\mathrm{K}_{2} \mathrm{O}\right)$ and
MnO show the reverse tendency. So in them, the increase of $\mathrm{Al}^{\mathrm{IV}}$ is balanced by increasing tri- and quadri-valent cations in the Y-site and by substitution of $(\mathrm{Na}+\mathrm{K})$ in the A-site of hornblende structure. On the other hand, the trend opposite to that of the former two types is noticed in the 
Table 2. Chemical compositions of hornblendes and the calculated $K_{D}$ values.

\begin{tabular}{|c|c|c|c|c|c|c|c|c|c|c|c|c|}
\hline \multirow{2}{*}{$\begin{array}{l}\text { Rock Type } \\
\text { Anal. No. }\end{array}$} & \multicolumn{3}{|c|}{ Myoj1n-1sh1 } & \multicolumn{3}{|c|}{ Komuro } & \multicolumn{2}{|c|}{ Iritabyuto } & \multicolumn{3}{|c|}{ Dark 1nclusion } & \multirow{2}{*}{$\frac{\text { Gabbro }}{13}$} \\
\hline & 3 & 1 & 4 & 19 & 20 & 21 & 23 & 26 & 37 & 42 & 41 & \\
\hline D.I. & 42.93 & .44 .45 & 49.65 & 45.78 & 50.33 & 51.31 & 59.06 & 64.18 & 35.84 & 48.09 & $62: 11$ & 29.06 \\
\hline $\mathrm{S} \mathrm{O}_{2}$ & 46.15 & 45.39 & 44.44 & 46.77 & 45.68 & 45.07 & 42.49 & 44.26 & 44.61 & 43.03 & 43.63 & 44.95 \\
\hline $\mathrm{TiO}_{2}$ & 1.59 & 1.72 & 1.96 & 2.19 & 2.34 & 2.77 & 2.97 & 2.00 & 1.65 & 2.15 & 1.65 & 2.15 \\
\hline $\mathrm{Al}_{2} \mathrm{O}_{3}$ & 8.38 & 8.45 & 8.49 & 7.68 & 8.23 & 8.56 & 8.68 & 7.90 & 9.75 & 10.12 & 9.07 & 9.16 \\
\hline $\mathrm{Fe}_{2} \mathrm{O}_{3}$ & 3.01 & 2.01 & 3.86 & 2.14 & 2.58 & 3.46 & 5.62 & 4.69 & 3.23 & 4.68 & 4.94 & 2.88 \\
\hline $\mathrm{FeO}$ & 13.34 & 15.20 & 14,49 & 13.99 & 15.48 & 15.51 & 14.95 & 16.17 & 16.29 & 15.22 & 16.03 & 15.42 \\
\hline Yno & 0.43 & 0.47 & 0.54 & 0.45 & 0.53 & 0.58 & 0.64 & 0.64 & 0.47 & 0.55 & 0.62 & 0.37 \\
\hline $\mathrm{MgO}$ & 12.03 & 11.14 & 10.25 & 12.52 & 10.55 & 9.51 & 8.28 & 8.40 & 10.04 & 9.02 & 7.82 & 10.47 \\
\hline $\mathrm{CaO}$ & 11.55 & 10.90 & 11.16 & 10.78 & 10.72 & 10.52 & 11.03 & 11.23 & 10.15 & 11.00 & 11.30 & 10.49 \\
\hline $\mathrm{Na}_{2} \mathrm{O}$ & 1.06 & 1.12 & 1.38 & 0.92 & 1.27 & 1.22 & 1.29 & 1.28 & 1.30 & 1.18 & 1.13 & 1.16 \\
\hline $\mathrm{K}_{2} \mathrm{O}$ & 0.60 & 0.62 & 0.79 & 0.42 & 0.42 & 0.53 & 1.02 & 0.80 & 0.55 & 0.60 & 1.06 & 0.60 \\
\hline $\mathrm{H}_{2} \mathrm{O}+$ & 1.91 & 2.14 & 2.08 & 2.18 & 2.05 & 2.31 & 2.25 & 2.10 & 2.15 & 2.13 & 2.25 & 2.15 \\
\hline $\mathrm{B}_{2} \mathrm{O}-$ & 0.18 & 0.14 & 0.08 & 0.18 & 0.21 & 0.16 & 0.12 & 0.07 & 0.11 & 0.11 & 0.08 & 0.08 \\
\hline Total & 100.23 & 99.30 & 99.52 & 100.22 & 100.06 & 100.20 & 99.34 & 99.54 & 100.30 & 99.79 & 99.58 & 99.88 \\
\hline Si & 6.815 & 6.783 & 6.675 & 6.862 & 6.797 & 6.699 & 6.466 & 6.717 & 6.641 & 6.475 & 6.615 & 6.688 \\
\hline $\mathrm{Al}^{\mathrm{IV}}$ & 1.185 & 1.217 & 1.325 & 1.138 & 1.203 & 1.301 & 1.534 & 1.283 & 1.349 & 1.525 & 1.385 & 1.312 \\
\hline $\mathrm{Al}^{\mathrm{VI}}$ & 0.271 & 0.269 & 0.175 & 0.188 & 0.238 & 0.196 & 0.020 & 0.128 & 0.349 & 0.267 & 0.233 & 0.291 \\
\hline$T \mathbf{T}$ & 0.176 & 0.193 & 0.221 & 0.241 & 0.261 & 0.309 & 0.339 & 0.228 & 0.184 & 0.243 & 0.188 & 0.240 \\
\hline $\mathrm{Fe}^{+3}$ & 0.333 & 0.225 & 0.435 & 0.236 & 0.288 & 0.386 & 0.642 & 0.534 & 0.361 & 0.528 & 0.562 & 0.321 \\
\hline $\mathrm{Fe}^{+2}$ & 1.641 & 1.893 & 1.814 & 1.710 & 1.920 & 1.921 & 1.896 & 2.045 & 2.021 & 1.908 & 2.025 & 1.912 \\
\hline 伯 & 0.054 & 0.059 & 0.069 & 0.056 & 0.067 & 0.073 & 0.082 & 0.082 & 0.059 & 0.070 & 0.079 & 0.047 \\
\hline $\mathrm{Mg}$ & 2.665 & 2.497 & 2.309 & 2.755 & 2.355 & 2.120 & 1.890 & 1.912 & 2.242 & 2.036 & 1.779 & 2.337 \\
\hline $\mathrm{Ca}$ & 1.827 & 1.745 & 1.796 & 1.695 & 1.709 & 1.675 & 1.798 & 1.826 & 1.619 & 1.773 & 1.836 & 1.672 \\
\hline $\mathrm{Na}$ & 0.303 & 0.324 & 0.401 & 0.261 & 0.366 & 0.351 & 0.380 & 0.376 & 0.375 & 0.344 & 0.332 & 0.334 \\
\hline $\mathrm{k}$ & 0.113 & 0.118 & 0.151 & 0.079 & 0.080 & 0.101 & 0.198 & 0.155 & 0.105 & 0.115 & 0.205 & 0.114 \\
\hline $\mathrm{OH}$ & 1.880 & 2.132 & 2.083 & 2.132 & 2.034 & 2.289 & 2.283 & 2.125 & 2.134 & 2.137 & 2.274 & 2.132 \\
\hline $\mathrm{Pe}^{+2}$ & 1.62 & 1.32 & 1.27 & 1.61 & 1.23 & 1.10 & 1.00 & 0.93 & 1.10 & 1.07 & 0.88 & 1.22 \\
\hline$x_{p}$ & 0.74 & 0.77 & 0.81 & 0.74 & 0.80 & 0.81 & 0.93 & 0.82 & 0.92 & 0.88 & 0.86 & 0.86 \\
\hline
\end{tabular}

Analyst: H. Tanaka.

hornblendes from the Iritabyuto type, though they have a lower content of $\mathrm{SiO}_{2}$ and higher contents of $\left(\mathrm{Na}_{2} \mathrm{O}+\mathrm{K}_{2} \mathrm{O}\right)$ and $\mathrm{MnO}$ than those from the former. The hornblendes from the dark inclusions are slightly richer in $\mathrm{Al}_{2} \mathrm{O}_{3}$ than those from the three types. The hornblendes mentioned above are all rich in $\mathrm{TiO}_{2}$ and have more than 1.1 atoms of $\mathrm{Al}^{\mathrm{IV}}$ in a half unit cell.

One pair of biotite and hornblende from the gabbro have compositions very similar to those from the Myojin-ishi and Komuro types, and their $\mathrm{Mg} / \mathrm{Fe}$ ratios are not so high as would be expected from the low
D.I. value (i.e. 29.06) of the host rock.

\section{Distribution OF Mg AND $\mathrm{Fe}^{+2}$ IN Coexisting BIOTITE AND HORNBLENDE}

Here we assume the exchange reaction of $\mathrm{Mg}$ and $\mathrm{Fe}^{+2}$ between biotite and hornblende is expressed as:

$1 / 5 \mathrm{~K}_{2} \mathrm{Mg}_{5} \mathrm{AlSi}_{5} \mathrm{Al}_{3} \mathrm{O}_{20}(\mathrm{OH})_{4}+1 / 4 \mathrm{Na}_{0.5} \mathrm{Ca}_{2}$ $\mathrm{Fe}^{+2}{ }_{4} \mathrm{AlSi}_{6.5} \mathrm{Al}_{1.5} \mathrm{O}_{22}(\mathrm{OH})_{2}=1 / 5 \mathrm{~K}_{2} \mathrm{Fe}^{+2}{ }_{5} \mathrm{AlSi}_{5}$ $\mathrm{Al}_{3} \mathrm{O}_{20}(\mathrm{OH})_{4}+1 / 4 \mathrm{Na}_{0.5} \mathrm{Ca}_{2} \mathrm{Mg}_{4} \mathrm{AlSi}_{6.5} \mathrm{Al}_{1.5} \mathrm{O}_{22}$ $(\mathrm{OH})_{2}$.

The apparent distribution coefficient of $\mathrm{Mg}$ $\mathrm{Fe}^{+2}$ is: 
$\mathrm{K}_{\mathrm{D}}=\left(\mathrm{Mg} / \mathrm{Fe}^{+2}\right)$ biotite $/\left(\mathrm{Mg} / \mathrm{Fe}^{+2}\right)$ homblende. In Table 2 are shown the calculated $\mathrm{K}_{\mathrm{D}}$ values for the pairs analysed. The $K_{D}$ value increases in the Myojin-ishi and Komuro types, and decreases in the Iritabyuto type and the dark inclusions with increasing D.I. of the host rocks. The values of the former group are smaller than those of the latter group

In general, the apparent distribution coefficient $K_{D}$ is a function of temperature, pressure and the chemical compositions of the system. In the Tabito plutonic complex, the $K_{D}$ value covers a fairly wide range from 0.74 to 0.93 , and from -0.30 to -0.07 in logarithm. It is evident in Fig. 1 that the $K_{D}$ value is controlled mainly by the $\mathrm{Al}^{\mathrm{IV}}$ content in hornblende. Although some analysed hornblendes show zonal structure, all $K_{D}$ values are plotted on or near a straight line in Fig. 1. The fact indicates that the analysed biotite-hornblende pairs were equilibrated on the $\mathrm{Mg}$ $\mathrm{Fe}^{+2}$ partition to some extent.

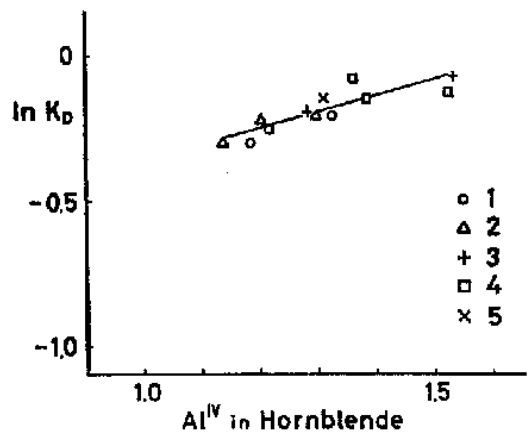

Fig. 1. Relations between the logarithmical value of $\mathrm{K}_{\mathrm{D}}$ and the $\mathrm{Al}^{\mathrm{IV}}$ content in hornblende for the rocks from the Tabito plutonic complex.

1: The Myojin-ishi type, 2: The Komuro type,

3: The Iritabyuto type, 4: Dark inclusions,

5: Gabbroic rock.

In Figs. 2 and 3 , the logarithmical values of $K_{D}$ for the total 72 biotite-

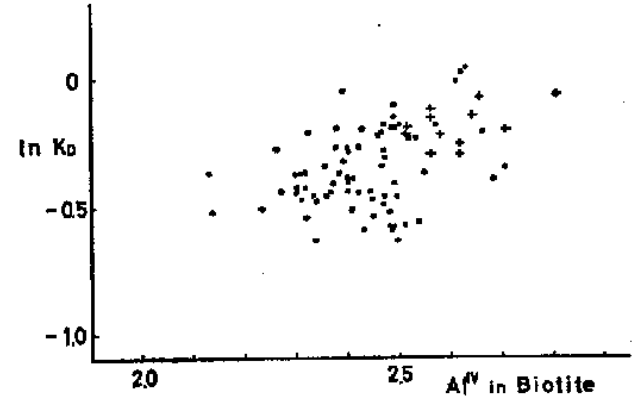

Fig. 2. Relations between the logarithmical value of $K_{D}$ and the $A l^{I V}$ content in biotite for the calc-alkaline granitic rocks of various districts. Twelve data from the Tabito plutonic complex are shown by plus symbols.

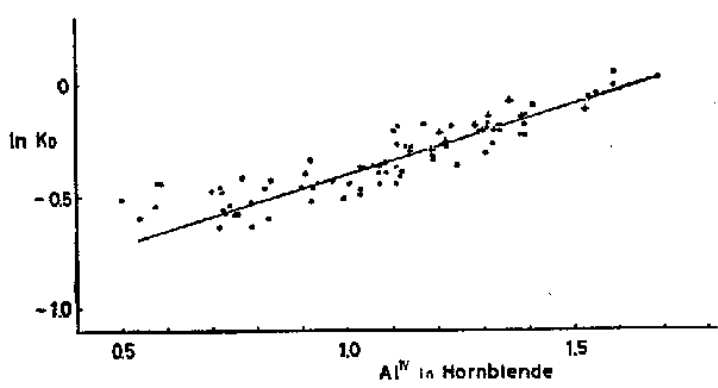

Fig. 3. Relations between the logarithmical value of $\mathrm{K}_{\mathrm{D}}$ and the $\mathrm{Al}^{\mathrm{IV}}$ content in hornblende for the calc-alkaline granitic rocks of various districts. Plus symbols the same as used as in Fig. 2.

hornblende pairs from the calc-alkaline granitic rocks of various districts are plotted versus the $\mathrm{Al}^{\mathrm{IV}}$ contents in biotite and hornblende, respectively. The data used are from the contributions by Haslam (1968), Dodge et al. (1968, 1969), Kanisawa (1969, 1972, 1974), Dodge and Ross (1971), Hietanen (1971), Kato (1972), Albuquerque (1973, 1974) and Kato and Tanaka (1973). Some data that show significant deviations from others in each district are omitted in Figs. 2 and 3 . These abnormal data could be ascribed to the following reasons:

1. The equilibrium condition was not 
attained for the distribution of $\mathrm{Mg}$ $\mathrm{Fe}^{+2}$ in the coexisting biotite and hornblende.

2. The separation or chemical analysis of the mineral was not complete.

3. Although in a few cases, the aberrant values of $\mathrm{K}_{\mathrm{D}}$ were obtained from the pairs of which the mineral chemistry seemed to be reflected by the extremely oxidized or reduced conditions. This feature may be a sign of the dependance of $\mathrm{K}_{\mathrm{D}}$ on the chemistry of the rocks.

For comparison, the data from the Tabito plutonic complex are plotted together in Figs. 2 and 3.

With respect to biotite, no consistent relation is noticed between the logarithm of $\mathrm{K}_{\mathrm{D}}$ and the $\mathrm{Al}^{\mathrm{Iv}}$ content. On the contrary in hornblende, the same trend as in the case of the Tabito plutonic complex can be seen, and all data are plotted near the straight line in Fig. 3. Accordingly it is universally said that the logarithmical values of $\mathrm{K}_{\mathrm{D}}$ for $\mathrm{Mg}$ and $\mathrm{Fe}^{+2}$ in coexisting biotite and hornblende are directly proportional to the $\mathrm{Al}^{\mathrm{IV}}$ contents in hornblendes. The fact is in harmony with the theory of Ramberg (1952) that the substitution of $\mathrm{Al}$ for $\mathrm{Si}$ influences the lattice oxygen to favor $\mathrm{Fe}$ in preference to $\mathrm{Mg}$ in octahedral sites.

The similar compositional effect of hornblende upon the distribution coefficient for $\mathrm{Mg}$ and $\mathrm{Fe}^{+2}$ are also seen in clinopyroxone-hornblende and orthpyroxene-hornblende pairs (Ray and Sen, 1970). In conclusion, the $\mathrm{Al}{ }^{\mathrm{IV}}$ content in hornblende exerts a strong influence on the $\mathrm{Mg}-\mathrm{Fe}^{+2}$ distribution in pairs involving hornblende. Therefore, when the apparent distribution coefficient is used as the indicator of temperature or pressure, much attention must be paid to the compositional effect of hornblende.

\section{AGKNOWLEDGEMENTS}

The present author wishes to express his sincere thank to Associate Prof. Hitoshi Onuki of Tohoku University for valuable suggestions and critical reading of the manuscript. Sincere appreciation is extented to Emeritus Prof. Kotora Hatai of Tohoku University for his courtesy to read the manuscript critically. He is grateful also to Prof. Tadashi Konda and Dr. Tadahide Ui of Yamagata University, and Dr. Yuzo Kato of Tohoku University for helpful suggestions and advices.

\section{REFERENCES}

de Albuquerque, C.A.R. (1973), Geochemistry of biotites from granitic rocks, Northern Portugal, Geochim. Cosmochim. Acta, 37, 1779-1802. (1974), Geochemistry of actinolitic hornblendes from tonalitic rocks, Northern Portugal, Geochim. Cosmochim. Acta, 38, 789803.

Dodge, F.C.W., Papike, J.J. and Mays, R.E. (1968), Hornblendes from granitic rocks of the Central Sierra Nevada batholith, California, Jour. Petrol., 9, 378-410.

— Smith, V.C. and Mays, R.E. (1969), Biotites from granitic rocks of the Central Sierra Nevada batholith, California, Jour. Petrol., 10, 250-271.

- and Ross, D.C. (1971), Coexisting hornblendes and biotites from granitic rocks near the San Andreas fault, California, Jour. Geol., 79. 158-172.

Fukasawa, T. and Onuki, H. (1972), On the gabbroic rocks in the northern Abukuma mountains, Jour. Japan. Assoc. Min. Petrol. Econ. Geol., 67, 1-10. (in Japanese with English abstract).

Gorbatschev, R. R. (1972), Fe and Mg distribution between coexisting biotites and Ca-amphiboles, Rep. 24 th I. G. C. Sec. 10, 93-98.

Haslam, H.W. (1968), The crystallization of intermediate and acid magma at Ben Nevis, Scotland. Jous. Petrol., 9, 84-104.

Hietanen, A. (1971), Distribution of elements in biotitehornblende pairs and in an orthopyroxene-clinopyroxene pair from zoned plutons, Northern Sierra Nevada, California, Contr. 
Min. Petrol. 30, 161-176.

Kanisawa, S. (1969), On the Hitokabe granodioritic mass, Kitakami mountainland, Jour. Japan. Asşoc. Min. Petrol. Econ. Geol., 62, 275-288. (in Japanese with English abstract).

(1972), Coexisting biotites and hornblendes from some granitic rocks in southern Kitakami mountains, Japan, Jour. Japan. Assoc. Min. Petrol. Eton. Geol., 67, 332-344.

- (1974), Granitic rocks closely associated with the Lower Cretaceous volcanic rocks in the Kitakami mountains, Northeast Japan, Jour. Geol. Soc. Japan, 80, 355-367.

Kato, Y. (1972), Petrology of the Orikabe granitic body, Kitakami mountainland, Jour. Japan. Assoc. Min. Pelrol. Econ. Geol., 67, 50-59. (in Japanese with English abstract).

- and Tanaka, H. (1973), Petrology of the Kinkasan granitic body, Kitakami mountains, Jour. Japan. Assoc. Min. Petral. Econ. Geol., 68, 395-403. (in Japanese with English abstract).

Maruyama, T. (1972), Geochronological study of the granites distributed over Gosaisho-Takanuki district, southern part of the Abukuma plateau. Magna, 31, 9-13. (in Japanese).

Ramberg, H. (1952), Chemical bonds and distribution of cations in silicates, Jour. Geol., 60, $331-355$.

Ray, S. and Sen, S.K. (1970), Partitioning of major exchangeable cations among orthopyroxene; calcic pyroxene and hornblende in basic granulites from Madras, $N$. Jb. Min. Abh., 114 , 6I-88.

Shido, F. (1958), Plutonic and metamorphic rocks of the Nakoso and Iritono districts in the central Abukuma plateau, Jour. Fac. Sci., Univ. Tohyo, Sec. II, 11, 131-217.

Tanaka, H. (1974). On the Tabito composite mass in the Abukuma plateau, Jour. Japan. Assoc. Min. Petrol. Econ. Geol., 69, 18-31. (in Japanese with English abstract).

Ueno, N. (1968), Rb-Sr isotopic studies on granitic rocks and metamorphic rocks in the Ryoke, Abukuma and Hida metamorphic belt, Central Japan, Tokyo Univ., Docter thesis.

\section{花崗岩類中の共存する黒雲母と角閃石の $\mathrm{Mg}-\mathrm{Fe}$ 分配}

田中久啨隹

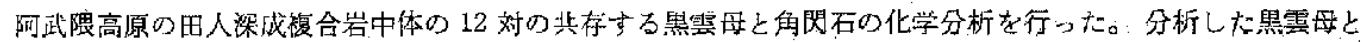

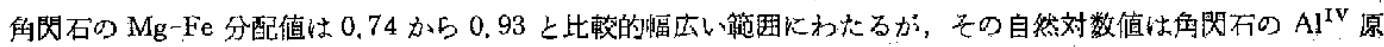

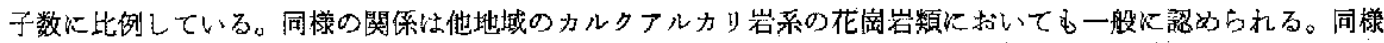

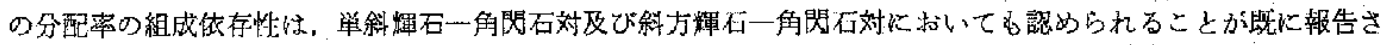

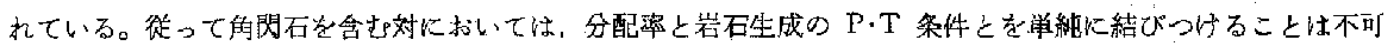

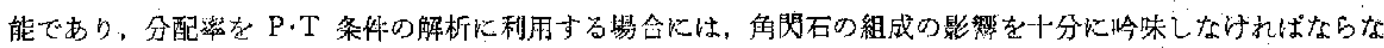
w。

The Myojin-ishi type

The Komuro type

The Iritabyuto type
明神伤型

小室型

入旅人型 